Portland State University

PDXScholar

1973

\title{
A reinterpretation of the Oregon school bill of 1922 : the concept of the common school in progressive America.
}

Stephen Louis Recken

Portland State University

Follow this and additional works at: https://pdxscholar.library.pdx.edu/open_access_etds

Part of the History Commons, and the Law Commons

Let us know how access to this document benefits you.

\section{Recommended Citation}

Recken, Stephen Louis, "A reinterpretation of the Oregon school bill of 1922 : the concept of the common school in progressive America." (1973). Dissertations and Theses. Paper 4416.

https://doi.org/10.15760/etd.6295

This Thesis is brought to you for free and open access. It has been accepted for inclusion in Dissertations and Theses by an authorized administrator of PDXScholar. Please contact us if we can make this document more accessible: pdxscholar@pdx.edu. 
AN ABSTRACT OF THE THESIS OF Stephen Louis Recken for the Master of Arts in History presented March 12, 1973.

Title: A Reinterpretation of the Oregon School Bill of 1922:

The Concept of the Common School in Progressive America.

APPROVED BY MEMBERS OF THE THESIS COMMITTEE:

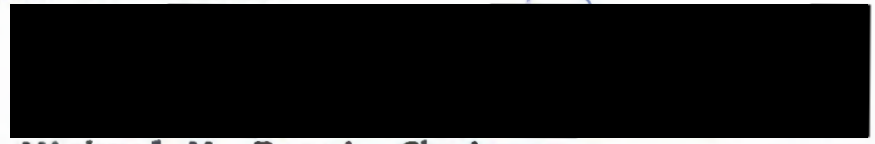

Michael M. Passi, Chairman

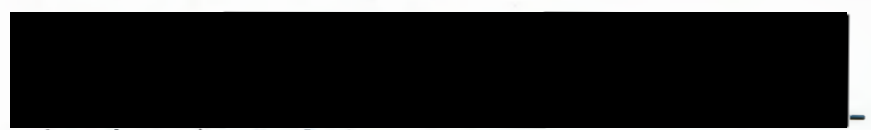

Charles A. LeGuin

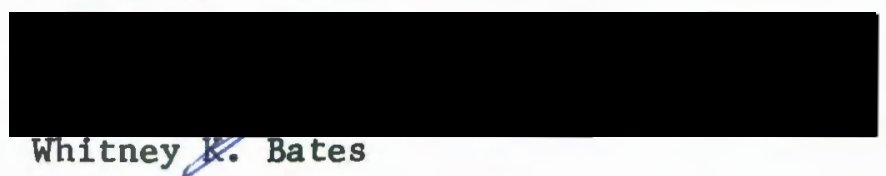

The Oregon School Bill of 1922 would have required all school age children to attend public schools. Beginning as an initiative measure sponsored by the Scottish Rite Masons it was passed by the voters in the general election in the Fall of 1922. Shortly after its passage representatives of private and parochial schools began a court battle against the bill which ended in the United States Supreme Court. Affirming the decision of a lower court it declared the Bill to be unconstitutional. While public interest in the Bill was great during the campaign, it soon dwindled and by 1925 the School Bill held little interest but to historians.

The Oregon School Bill was the culmination of an ancient tradition in American 1ife. Incorporating the basic tenents of the colonial coumon school, it was a concept that had been refined and updated for 
many generations. Essentially it was the basis for an ideal society. Citizens and educators believed that by bringing children from diverse backgrounds together in the classroom, lessons of democracy and harmony could be nurtured which would remain with the child throughout his life. The school became a seed from which society was the eventual flower. The champions of the Oregon School Bill worked from the same assumptions that the Puritan forefathers did, and for many of the same reasons.

Historians such as David Tyack and Kenneth Jackson, however, have come to another conclusion concerning the School Bill. Noting that the Bill would have primarily affected ethnic groups, particularly Catholics, they have concluded that the Bill was founded in nativistic intolerance. Linking the Bill with such groups as the $\mathrm{Ku}$ Klux Klan they have attempted to show that men were motivated to support the Bill from feelings of fear and mistrust. This interpretation fits with the widely accepted picture of the "Tribal Twenties." If xenophobia was rampant in 1922, then the School Bill could have been a method of placating the apprehensions of "tight-lipped conservatives." Yet, to base our understanding on the immediate atmosphere of the 1920's, without taking note of tradition and precedent, is to distort a complex moment in man's history. Some of America's most venerable educators, men such as Horace Mann, Henry Barnard and John Dewey, have endorsed the common school model for the creation of the ideal society. They viewed it as a positive weapon for ameliorating the divisive tendencies in society. Unwilling to temporize, these men believed that the common school ought to take precedent 
over all other reform measures. While they did not agree as to what the role of the private school ought to be, they all saw it as contrary to the best interests of society. In short, the School Bill must be analyzed in view of these contributions to American education. While there were examples of bigotry and racism in the campaign for the School Bill, most of the proponents utilized arguments deve1oped from the tradition of the common school. Most spokesmen emphasized that compulsory public school education would make the classroom a melting pot in which class and race antagonisms would be sloughed off as children learned the lessons of understanding and cooperation from first hand experience. Oregonians were attracted to the measure because it seemed to mean that all children, despite their background, would receive an equal start in life. As in all times there were hate mongers, but they were not in the forefront of the campaign for the Bill.

The Oregon School Bill could not be termed a tolerant measure. Instead, it was merely a handy and simple solution which seemed to meet the needs of society. By examining the School Bill from these perspectives one not only gains a more complete view of the Bill itself but one also finds that the roots of the twenties reach far back into the nineteenth century. Indeed, the School Bill was part of the Progressive model for a better society. The Oregon School Bill, much like its colonial counterpart, represented a significant attempt by Americans to shape their environment. 
A REINTERPRETATION OF THE OREGON SCHOOL BILL OF 1922:

THE CONCEPT OF THE COMMON SCHOOL IN PROGRESSIVE AMERICA

by

STEPHEN LOUIS RECKEN

A thesis submitted in partial fulfillment of the requi rements for the degree of

MASTER OF ARTS

in

HISTORY

Portland State University

1973 
TO THE OFFICE OF GRADUATE STUDIES:

The members of the Committee approve the thesis of

Stephen Louis Recken presented March 12, 1973.

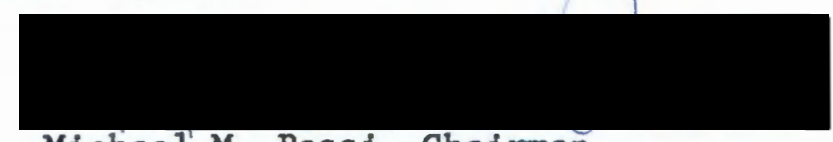

Michael M. Passi, Chairman

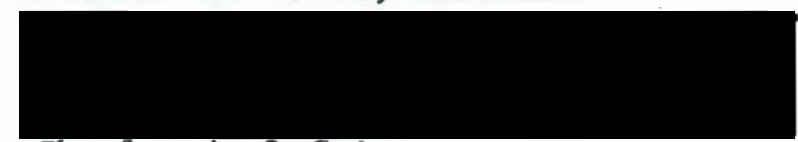

Charles A. LeGuin

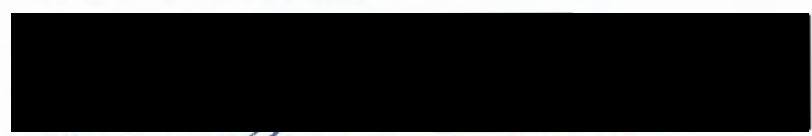

Whitney Bates

\section{APPROVED:}

Jesse Limilmore, Head, Department of History

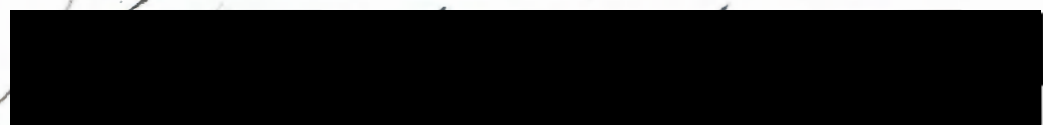

Bavid D. Clark, Dean of Graduate Studies

March 12, 1973 
TABLE OF CONTENTS

PAGE

PREFACE

CHAPTER

I INTRODUCTION . . . . . . . . . . . . . 1

II DEVELOPMENT OF THE CONCEPT OF THE COMMON SCHOOL . • 13

III THE CAMPAIGN FOR THE OREGON SCHOOL BILL . . . . . 29

IV COURT REVIEW AND REJECTION . . . . . . . . . 41

V CONCLUSION . . . . . . . . . . . . . 51

BIBLIOGRAPHY . . . . . . . . . . . . 58 


\section{PREFACE}

The basic source for any research on the Oregon School Bill is the Lutheran Schools Committee Collection at the Oregon Historical Society. To be sure, the collection is very complete and offers source material on almost all aspects of the Bill. Its only disadvantage, however, is that many newspaper clippings are loose in folders, and carry no more information than the name of the paper and the date. For this reason, therefore, many footnotes in this paper are not as complete as standards of scholarship might dictate. In all cases, I have tried to give as complete information as possible. Several people have been instrumental in bringing this project to fruition. I am particularly indebted to Professor Michael Passi who has read at least three versions and was primarily responsible for conceptualizing the thesis itself. Similarly, I am also grateful to Professor Whitney Bates who read one of the last versions and offered many helpful suggestions. Ms. Paulette Sanders, through her typing skills, transformed a pile of paper scraps into a finished product. In many ways, Sarah McMillan Recken sponsored this project. This thesis is dedicated to my grandmother, Josephine F. Heath. 


\section{CHAPTER I}

\section{INTRODUCTION}

The Oregon School Bill of 1922 required that all school age children attend public schools. Although the measure never took effect it would have put private and parochial schools out of business. ${ }^{*}$ Because the Bill primarily affected ethnic groups, particularly Catholics, scholars such as David Tyack have concluded that the Bill was rooted in intolerance and bigotry. Further, they have drawn on such evidence as the meteoric rise of the Ku Klux Klan to demonstrate a grass roots nativism among the citizens of Oregon. This interpretation, relying on the immediate atmosphere of the post World War I Era, neatly lends itself to the widely accepted view of the "tribal twenties."

This approach leaves several important areas unexplored. David Tyack would have us believe that the School Bill sprang full blown from such groups as the Klan. In fact, the Bill was largely the culmination of a sturdy and venerable tradition in American education, embodied in the concept of the common school.

Arising out of the exigencies of the Puritan world, the common school represented an attempt to mold children into the kind of citizens society desired. Refined by leading educators such as Mann, 
Barnard and Dewey, the common school became an integral part of the American mythos. Most historians neglect this aspect of the Oregon School Bill.

This is not to say that the Ku Klux Klan did not have an important role in the adoption of the School Bill. At some points the links were quite overt. The Klan openly campaigned for the Bill and was probably instrumental in its initiation. In keeping with the standard interpretation, the rhetoric of some Klan leaders was quite vicious. And perhaps most importantly, the Klan membership grew spectacularly during this time period and received much publicity. However, the Klan did not live up to its reputation for violence and disorder. It acted like a civic and "patriotic" fraternal group seeking to guard traditional values. In short, one must look beyond groups such as the Klan in understanding the Oregon School Bill.

The Bill had its inception in an initiative petition drive early in the summer of 1922 . The sponsors of the Bill, the Scottish Rite Masons, quickly collected enough signatures to place the measure on the general election ballot of $1922 .^{2}$ The Bill was passed by the voters of Oregon by a margin of about 12,000 votes of some 229,000 cast. It was to take effect in September of 1926. However, soon after the election, groups with an interest in private and parochial schools filed suit against those whose responsibility it would be to enforce the measure, hoping to block it. A three man District Court in Portland ruled in favor of the private school interests in June of 1924. Representatives of the State of Oregon appealed the decision to the United States Supreme Court where the School Bill was also 
ruled unconstitutional. The Oregon Compulsory School Law never took effect and soon after the Supreme Court ruling it held little interest for anyone except historians.

The campaign preceding the general election of 1922 was marked by intense controversy. Besides the school measure, there was also great interest in the campaign for governor. In this case a Democrat won in a state where Republicans outnumbered Democrats three to one. Walter Pierce, the victorious Democratic nominee, is usually depicted as a bigot and a close ally of the Klan. Both sides in the school fight ran many newspaper advertisements presenting their views, and both sides held public meetings where persuasive speakers attempted to sway voters to their viewpoint. Likewise, newspapers covered the measure carefully. The people of oregon could not help but be involved in the controversies over the election of $1922 .{ }^{3}$

Despite the obvious role of the Klan in carrying the Oregon School Bill it is a mistake to assume that it was totally responsible for the Bill's passage. Moreover, it is important to separate the Klan's reputation from its actions in the School Bill controversy. The power and influence of the Klan in Oregon has been greatly overestimated, and the motives of its members have not really been accurately portrayed. More importantly, the aims of the School Bill goes far beyond the surface waves of uneasiness over heterogeneity. The rationale of the School Bill is rooted deep in the history of the nation and is in keeping with the highest aspirations of the Progressive Era. It is more accurate to see the School Bill as a reform measure than as a manifestation of paranoia. 
In the pages below I will attempt to summarize the various interpretations of the School Bill. It is my contention that a11 this material is very similar. The themes of racism, intolerance, nativism and hatred seem to recur continually. The implication is that the motivation for the School Bill arose full blown out of this atmosphere, while the tradition of the common school in American culture is ignored.

David Tyack's article, "The Perils of Pluralism: The Background of the Pierce Case," appears to sum up most of the historiography of the Oregon School Bill. While Tyack does take note of what he calls the "incongruous" arguments put forward by proponents of the Bi11, he seems to feel that they were far overshadowed by the forces of prejudice and paranoia. It is Tyack's thesis that the Bill was primarily directed at Catholics, and that its supporters were motivated by xenophobic distrust of groups who appeared to be a threat and who deviated from the norm. 4

Tyack regards the $\mathrm{Ku} \mathrm{Klux} \mathrm{Klan}$ as the instigator and perpetrator of the Oregon School Bill. He opens his article with a quotation from Luther Powe11, chief organizer of the Portland Klan:

To defend the common school is the settled policy of the Ku Klux Klan and with its white-robed sentinels keeping eternal watch, it shall for all time, with its blazing torches as signal fires, stand guard on the outer walls on the Temple of Liberty, cry out the warning when danger appears and take its place in the front rank of defenders of the public school.5

Tyack believes that because of the peculiar sense of urgency, anxiety and displacement found in the $1920^{\prime} \mathrm{s}$, nativists focused their concern on the public school. In his analysis the schools became the battleground on which to fight the enemies from within. 
Tyack brings together the sources of uneasiness and the corresponding solution by stating:

Was a cynical spirit abroad in the land, fed by H. L. Mencken, Sinclair Lewis and a host of muckraking historians and biographers? Then pass laws requiring textbook writers and teachers to be reverential toward folk heroes. The answer was clear: if society seemed centrifugal, schools must be forced to move in narrow circles of orthodoxy. Critics might ridicule the "booboisie," the tight lipped conservatives who called for laws against petting and flirting, who enacted prohibition, who baited Reds, who demanded the pious rewriting of history, who disclaimed monkey ancestors, but the majority could and did enact its alarm into school laws. And the consequences of the crusade for conformity were no joke, however comical the actors. 6

Tyack offers no adequate explanation for this. Although a similar plan had failed in Michigan, and Washington was meant to be next on the list after its neighboring state, Oregon, which already had a strong compulsory attendance law and was the only state where the movement for compulsory public education seemed to gain a real foothold. He can only conclude that

perhaps it was because Oregon did approximate the nativist ideal that partisans like the Klansmen chose it as a test case for compulsory education, for there the majority of citizens might be persuaded to support a state monopoly.7

Tyack takes care to point out the seeming contradictions between the traditional. ideology of the Klan and its support of the School Bill. Because the Klan had always promoted white supremacy it was ironic that it could favor mixing various races together in the classroom. Tyack wrote that

even more incongruous was the argument that the public school should mix children of all the people--all ethnic groups, all economic classes--in order to produce social solidarity: at its most eloquent the Klan rhetoric sounds like the plea of those integrationist liberals today who would make the public school a true "common school" by achieving a racial, ethnic and economic cross section in each classroom. 
Paraphrasing Klan leaders, Tyack states that "at stake was the fate of the public school, which was being 'ground to atoms' by quarreling sects." 8

Tyack concludes his article by stating:

But by the $1920^{\prime}$ s the old unconscious conservatism was fast disappearing, and the psuedo-conservative's chief recourse was an attempt to persuade the uncertain majority to force the minority to conform. "Thus came to an end the effort to regiment the mental life of Americans through coerced public school instruction, " observed the New Republic on learning the Court's decision. Thus came to an end this chapter of coercion, but the schools would remain a ready target for those who saw peril in pluralism.9

Kenneth Jackson's book, The Ku Klux Klan in the City, 1915-1930, is probably the most important work on the Klan for the period following the First World War. ${ }^{10}$ The primary contribution of this book is that it gives us a fairly precise description of the Klansman and his motives. Although Jackson devotes an entire chapter to Portland, he deals with the School Law in only a few pages, dwelling heavily on the themes of nativism and intolerance.

Jackson concludes that the Klan was a haven for those displaced by the forces of time. "The Ku Klux Klan provided a focus for the fears of alienated native Americans whose world was being disrupted." He adds that it was fear of change, not vindictiveness or cruelty, which was the basic motivation of the urban Klansman. He sums up his analysis by stating that the Klan:

prospered and grew to national power by capitalizing on forces already existent in American society: our readiness to ascribe all good or all evil to those religions, races, or economic philosophies with which we agree or disagree, and our tendency to profess the highest ideals while actually exhibiting the basest of prejudices. To examine the $\mathrm{Ku} \mathrm{Klux} \mathrm{Klan}$ is to examine ourselves.11 
Janet Bryant's research on the Oregon School Bill is the most exhaustive and the most precise to appear so far. ${ }^{12}$ In nearly two hundred pages she carefully documents the background of nativism in the Pacific Northwest and then focuses her attention on the Bill itself. Her interpretation resembles Tyack's. She states that the Klan and the Bill are inextricably linked:

In fact, it is my contention that the compulsory School Bill would not have been passed, at that time, with its continual appeal to prejudice and its extensive political activity without the active support of the Klan.13

However, according to Ms. Bryant, the Klansmen of this era did not fit our stereotyped image. She holds that, "the average Klansman was not a bigot, believed he was patriotic, and was defending the fundamentalist institutions of his country." If the School Bill brought strength to the Klan then the "declaration of its unconstitutionality helped break the Klan's powerhold in Oregon."14

Whatever its national publicity, or its later reputation, the Oregon Klan of the 1920's was a relatively innocuous organization. Only one act of violence has been connected with it and this was the work of only two or three Klansmen. Klan leadership immediately disclaimed any involvement in the crime. The $\mathrm{Klan}$ hierarchy took great care to insist that their group was peaceful and law abiding.

When Governor 01cott, the man defeated by Pierce in the election of 1922, made his famous speech condemning "riders of the night" the Klan was quite incensed that it should be singled out in this manner. The Klan of the 1920's was based on local autonomy and thus Klaverns across the country varied greatly in their interests and membership. 
The Klan's official policy was that it was devoted to "patriotic" and charitable causes; the weight of the evidence appears to substantiate this. 15

In denouncing the Klan, Olcott stated:

Dangerous forces are insidiously gaining a foothold in Oregon. In the guise of a secret society, parading under the name of the Ku Klux Klan, these forces are endeavoring to usurp the reins of government and are stirring up fanaticism, race hatred, religious prejudice and all of those evil influences which tend toward factional strife and civil terror.16

The reply by Klan leader, F. I. Gifford, made it clear that his organization had committed no crimes and was open to public scrutiny:

There has never been an outrage of any kind comitted in the State of Oregon that could be in any way be chargeable to the Ku Klux Klan but on the contrary if the authorities of the several counties and cities of the state were to make public the aid and assistance that they have received through our efforts in the matter of law enforcement and clean government: they would give the lie to the statement of Governor 0lcott. - . I also affirm that if he had evinced any interest in this organization the information would have been cheerfully given by myself or any other officer of the Ku Klux Klan.17

One student of the $\mathrm{Klan}$ states that 70 per cent of its membership joined out of a sincere desire for reform. Her estimate, based upon analysis of primary sources, was that only 5 per cent of the membership could be termed "anti-society."18 Further, the life of the Oregon Klan was of short duration. By 1926 its members had deserted as fast as they had joined. Men joined the Klan looking for simple answers, and finding none, quietly left. Further, the national leadership was continually embroiled in struggles within the organization.

Careful examination of newspapers during the 1920's reveals that people of the period did not take the Klan as seriously as we often do 
today. The following article reveals what happened when a Klansman solicited the signature of a Knight of Columbus to have the Oregon School Bill placed on the Fall ballot:

\section{Klansman and Knight Clash}

On yer fair concrete sward afront ye Y.M.C.A. a Knight of ye Ku Klux Klan and a Knight of Columbus met in ye 1 is ts yesterday, and right merrilee did they thump and buffet one another until ye men of ye high Sheriff were called in by ye startled "Y" officials.19

In their attempts to interpret the Oregon School Bill, historians have failed to go beyond the immediate atmosphere of post World War I. It is my contention that the Bill was in keeping with the traditions of American education as well as the reform ideas of the Progressive Exa. In order to understand the Oregon School Bill of 1922 one must therefore return to the origins of public school education. To attempt to interpret the measure from the immediate atmosphere of post World War I, as Jackson and Tyack have done, is hardly sufficient. The proponents of the School Bill envisaged a system of public education wherein all children, from whatever economic levels or ethnic backgrounds, would attend class together. Thus, students from diverse circumstances would learn to work together and would gain mutual empathy; the results of these experiences they could carry forward for the rest of their lives. The inspiration for this type of school system did not come from the "tribal twenties" but instead from America's most respected and venerable educators. Men such as Horace Mann and John Dewey saw class distinctions as one of the primary enemies of democracy. To combat class stratification and to give equal opportunity to all of the 
nation's children they endorsed the concept of the common school. Men such as these, who charted the course which education was to follow, saw the common school as the salvation of the nation.

Therefore, in Chapter Two I shall examine the traditions of the "common school" in America. I will use the writings of men such as Horace Mann and Henry Barnard to show the heritage of the common school from colonial times. These men, writing in the early part of the nineteenth century, regarded the common school as a flexible tool which could be applied to any need the nation might face. After summarizing the thinking of these men I move to John Dewey and the era of Progressivism. While Mann and Barnard merely expanded on a tradition rooted deeply in American culture, John Dewey applied the concept of the common school to meet urgent and pressing needs arising from the coming of the urban age and accompanying problems of immigration and industrialization. Chapter Three will deal with the campaign for the Bill itself. While most historians have merely drawn upon the speeches of several Klan leaders as evidence that the Bill was intolerant, I hope to demonstrate that the measure was justified in terms familiar to Oregonians in the early 1920's. 
CHAPTER I

FOOTNOTES

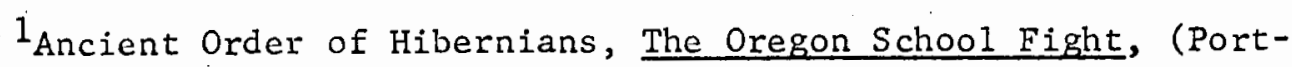
land: A. B. Cain, 1924), p. 2 .

${ }^{2}$ of course the Masons are traditionally an anti-Catholic group, but that does not seem to be their motivation in this case. The inspiration for the Bill came out of national Masonic policy, yet it still created controversy among the members at the local level.

${ }^{3}$ See Oregon Historical Society MSS 非46, particularly File 非22.

${ }^{4}$ David Tyack, "The Perils of Pluralism," American Historical Review, IXX (October, 1968), p. 74.

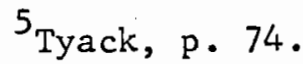

6 Tyack, p. 75 .

7 Tyack, p. 78 .

8 Tyack, p. 80 .

$9_{\text {Tyack, p. } 98 .}$

10 Kenneth T. Jackson, The Ku Klux Klan in the City 1915-1930, (New York: Oxford University Press, 1967).

$11_{\text {Jackson, p. } 249 .}$

12 Janet Bryant, "The Ku Klux Klan and the Oregon Compulsory School Bill," (unpublished M.A.T. thesis, Reed College, 1970).

13 Bryant, p. 78.

14 Bryant, p. 14.

${ }^{15}$ In the newspapers such as the Portland Telegram in the year 1922 one finds many stories about Klansmen ceremoniously marching into churches during services to donate money.

16 Portland Telegram, May 13, 1922, p. 2.

17 Portland Telegram, May 15, 1922, p. 1. 
CHAPTER I

FOOTNOTES, CONT.

${ }^{18}$ Bryant, p. 78. This is her term which I admit is imprecise. ${ }^{19}$ Portland Telegram, June 16, 1922, p. 1 . 
CHAPTER II

DEVELOPMENT OF THE CONCEPT OF THE COMMON SCHOOL

From colonial times to the present, American education has developed along fairly clear cut lines. Perhaps the most important and enduring tradition to emerge is that of the common school. Arising out of the needs of colonial America, it has been successively reshaped to meet the new needs and respond to new problems as they have arisen.

Lawrence Cremin, in his study, The American Common School, traces the origins of the common school to four factors: 1) the democratizing of politics, 2) the growth of the struggle to maintain social equality, 3) the change in the conception of man and society, 4) the rise of nationalism. ${ }^{1}$ Underlying these overt explanations were other, more subtle trends. One of these was the desire to found a community with a "common core of sentiment."

In essence, the proponents of the common school were seeking the nurture of a common core of sentiment, of value and of practice within which pluralism would not become anarchy. They were seeking, in a sense, a means of constant regeneration whereby the inevitable inequities arising out of freedom would not from generation to generation become destructive of its very sources. And realizing the threat of disunity potentially inherent in heterogeneity, they were seeking to build and inculcate a sense of community which would function, not at the expense of individualism, but rather as a firm framework within which individuality might be most effectively preserved.2

The expectations of the champions of the common school were extremely high. As Cremin points out, there was 
no limit to the modes and forms by which, in the process of such an education the noble and generous principles of pure patriotism may be illustrated and enforced, and all narrow and sectional prejudices checked and controlled, if not rooted out.

He concludes:

The conception which this reform group formulated of a school compatible with, and tending uniquely to maintain, the kind of republican society that developed in America in the early nineteenth century, emerged as a most positive educational ideal--the American common school. It was a school to embrace the whole community--ideally common to the young of all classes and creeds. It was a school uniquely charged with the responsibilities of preparing the young of the new republic to take their places in its adult society. It was a school which was to be truly the child of the community-supported by it, controlled by it, used by it, and serving it. And it was to provide for the young that which no other institution could furnish--the experience of democratic association within a genuine miniature of a democratic society. 3

Of all the advocates of the common school none had a more profound influence than Horace Mann. Like many other theorists his thinking is not always consistent and it seems to change with time. At any one time he is both a liberal and a conservative, radical yet reactionary. Despite the apparent fluidity of his thinking, Mann's ideas seemed to pervade the mid-nineteenth century.

At the center of Mann's philosophy was the common school, to which he attributed a huge array of potential benefits including the opportunity for unlimited moral elevation. He noted that,

Never will wisdom preside in the halls of legislation and its profound utterances be recorded on the statute books until common schools . . shall create a more far seeing intelligence and a purer morality than has ever existed among the communities of man.

Mann's enthusiasm for the common school was apparently unbounded. In his Tenth Annual Report, first published in 1847, he wrote: 
As an innovation upon all preexisting policy and usages, the establishment of Free Schools was the boldest ever promulgated, since the commencement of the Christian era. . . Two centuries now proclaim it to be as wise as it was courageous, as beneficient as it was disinterested. It was one of those grand mental and moral experiments whose effects can not be determined in a single generation. ${ }^{4}$

The common school was not to be specifically for the common people and thus possibly of inferior quality, but instead common in that all children, from whatever backgrounds, would attend. Mann was acutely aware of the multiplicity of ethnic, social and religious groups in America and he feared that these divisions might forever keep the nation in turmoil. His answer was the common school, where diversity would be broken down and replaced by a new public philosophy, a new sense of community. As Cremin points out, "His efforts were to use education to fashion a new American character out of a maze of conflicting cultural traditions." 5

Thus, for Mann, the common school was to be the basis for attacking all social evils. It was the foundation for unlimited social progress and the perfection of American life and institutions. The common school would become the "great equalizer" of the human condition, the "balance wheel of the social machinery" and the "creator of wealth undreamed of." That democracy in microcosm, the classroom, would give children the tools of mutual understanding and cooperation that they would carry until the end of their lives. Crime would be diminished because citizens would know better how to achieve comfortable and prosperous lives. Health would increase as people learned to care for themselves. Education would even prevent the masses from resorting to violence to initiate social change. The benefits from the 
common school, Mann promised, were to be so great that there is little wonder that this concept captured the American imagination.

Like many intellectuals of his time Mann was caught up in the new "science" of phrenology, which became the psychological bas is for his view of the possibilities of the common school. More than simply the interpretation of character based on bumps on the skull, phrenology was highly complex and was thought to contain many insights. It theorized that the human mind was composed of thirty seven faculties, each unique to the individual. Contained in these faculties were both positive and negative characteristics such as acquisitiveness, loyalty and musical talent. Mann believed that enlightened schools could cultivate the positive and desirable traits while eradicating the negative ones. Schools could thus improve each student on an individual basis.

While Mann's background in phrenology was one basis for his educational theories, he also depended on religion. Mann's approach was to take the moral teachings of Judaism, Catholicism and Protestantism and combine them into a common theme of Universal Brotherhood. He believed that while it was the duty and obligation of the school to inculcate a sense of morality in students, he firmly believed that it must be nondenominational and nonsectarian. Above all else, the common school must remain "sacred from the ravages of the spirit of party and unblasted by the fiery breath of authority." 6 Being a Unitarian himself, Mann believed that one could teach a moral lesson without promulgating an ideology.

To suit his goals for the common school Mann advocated a fairly general curriculum. While most segments of his society equated 
education and apprenticeship, Mann remained steadfast to his broader social purposes.

The development of the common nature; the cultivation of the germs of intelligence, uprightness, benevolence, truth, that belong to all;--while special preparations for the field or for the shop, for the forum 7 or the desk, for the land or for the sea, are but incidents.

Above all else, the school must prepare the student for life itself. The elements of this preparation included literature, the skills of language, health education and vocal music. With these tools, and with the experience of working with others from diverse backgrounds, Mann felt a desirable society would inevitably result. The common school was to be a "wellspring of freedom" and a "ladder of opportunity." More importantly, perhaps, Mann believed that education could eradicate social class. He stated that:

Nothing but Universal Education can counter work this tendency to the domination of capital and the servility of labor. - . Education, then beyond all other devices of human origin, is the great equalizer of the conditions of men--the balance wheel of the social machinery. The spread of education, by enlarging the cultivated class or caste, will open a wider area over which the social feelings will expand; and, if this education should be universal and complete, it would do more than all things else to obliterate factitious distinctions in society. 8

Private schools did not fit well into Mann's design. To him, these schools perpetuated the very attitudes that his common schools would eradicate. He viewed these schools as an anachronistic relic from the European past

in which children are taught, from their tenderest years to wield the sword of polemics with fatal dexterity; and where the gospe1, instead of being a temple of peace, is converted into an armory of deadly weapons, for social, interminable warfare. 9 
Although Mann never advocated the abolition of private schools, he sought to make the common school of such high quality that parents would not desire to send their children to private institutions. In the end the interests of the school and the greater society were one.

The former is the infant, immature state of those interests, the latter their developed adult state. As the child is father to the man so may the training of the schoolroom expand into the institutions and fortunes of the state.

Nothing, therefore, could be more important to a society than its school system.

As each citizen is to participate in the power of governing others, it is an essential preliminary that he should be imbued with a feeling for the wants, and a sense of the rights of those whom he is to govern. . . . It becomes then a momentous question, whether the children in our schools are educated in reference to themselves and their private interests only, or with a regard to the great social duties and prerogatives that await them in after life. Are they so educated that, when they grow up, they will make better philanthropists and Christians, or only grander savages? 10

Henry Barnard, a second major figure in shaping the ideology of the common school, shared many of Mann's ideas and was also active in the mid-nineteenth century. Barnard once wrote to Mann that, "you are my guide, my hope, my friend, my fellow sufferer in the cause."11 While both men firmly believed that the concept of the common school offered great hope in the creation of a better society, it is important to note their differences. Barnard was far more conservative than was Mann. He enthusiastically endorsed the capitalist industrial system and the slave system of the South. In religion he was a fundamentalist. While both men are regarded as humanitarians and reformers, Barnard was far more interested than Mann in preserving the status quo. 
Ironically, however, while Horace Mann felt that private schools ought to be left alone to wither away, Barnard favored eliminating them by law. ${ }^{12}$ To Barnard the private school posed a grave threat to the realization of a harmonious society:

It classifies society at the root, by assorting children according to wealth, education, or outward circumstances of their parents into different schools; and educates children of the same neighborhood differently and unequally. These differences of culture, as to manners, morals and intellectual tastes and habits, begun in childhood and strengthened by differences in occupation, which are determined mainly by early education, open a real chasm between members of the same society, broad and deep, which equal laws and political theories cannot close. 13

Merle Curti has noted:

Fearing the disastrous results of class antagonism, he [Barnard] vigorously opposed private academies and favored the movement for public high schools in order that children of rich and poor might join hands and come to a mutual understanding.

An important ingredient in Barnard's thinking which we will also find in John Dewey is a careful examination of the role of class in society. Curti observes:

While it would be too much to say that he envisioned a society in which there were no classes and no class distinctions, he did desire an order in which personal dignity, virtue and merit would be reverenced regardless of wealth and rank, in which there should be "no populace, no common people," but where all ranks and occupations of men would enjoy the pleasure of taste and imagination, respectful manners and correct morals.

Moreover, Curti continues:

Barnard with his typically American individualism, thus defended the existing order of industrial capitalism, whose sores he would heal by a classless education and a philanthropic cooperation between rich and poor. 15

Mann and Barnard expanded on the colonial concept of the common school. Theirs was a relatively stable society, and much of their work 
was associated with convincing the public that funds for education were necessary expenditures for the good of the nation. They obviously thought that education could solve social problems, but it took John Dewey to recognize its broadest applications. The world which Dewey faced in the twentieth century was far different from that which Mann and Barnard faced in the mid-nineteenth century, but the solutions these men found were remarkably similar.

John Dewey is the transitional figure who bridges the gap between the heritage of the common school of post-colonial America and the realities of twentieth century, industrial America. Dewey took the concepts of men such as Mann and Barnard and applied them to the new problems the nation faced. Dewey's place as a Progressive, his dependence on the heritage of the past yet his unique dream of the future, is outlined in his book, Democracy and Education. As Lawrence Cremin points out,

Dewey set out in the volume to explore the meaning of democracy, science, evolution, and industrialism. He ended by writing the clearest, most comprehensive statement of the progressive education movement. . . Like any classic, the work was both a reflection and a criticism of its age. It orchestrated the many diverse strands of pedagogical progressivism into a single inclusive theory and gave them unity and direction. Its very existence lent vigor to the drive for educational reform. 16

The key to Dewey's thinking is his concept of social reform. Dewey sought to move the school out of isolation and into the cauldron of the struggle for a better life. He knew that the precepts of the past were inadequate for the present and the future. While some other progressives attached all of their reform ideas to a new system of 
education, Dewey recognized that reform must reach all facets of 1 ife.

Abandoning the models of the past, Dewey stated:

Our country is too big and too unformed, however, to enable us to trust to an impirical philosophy of muddling along, patching up here and there. . . a method checked up at each turn by results achieved .17

As Cremin wrote of Dewey, "Once again the classical idea of education as cultural aspiration is called to mind, though in the very formulation of his ideal Dewey transformed the meaning of culture."

Dewey took the political word democracy and applied the concept to all aspects of culture. 18 The destruction of political barriers separating men was not enough, "all reforms which rest simply upon the enactment of law, or the threatening of certain penalties, or upon changes in mechanical or outward arrangements, are transitory and futile."19 All of American 1ife, Dewey believed, including politics and education, must reflect a broad commitment to equality and sharing. In the following passage he outlines many themes which can be found throughout his writing:

The devotion of democracy to education is a familiar fact. The superficial explanation is that a government resting upon popular suffrage cannot be successful unless those who elect and who obey their governors are educated. Since a democratic society repudiates the principle of external authority, it must find a substitute involuntary disposition and interest: these can be created only by education. But there is a deeper explanation. A democracy is more than a form of government: it is primarily a mode of associated living, of conjoint communicated experience. The extension in space of the number of individuals who participate in an interest so that each has to refer his own action to that of others, and to consider the action of others, and to consider the action of others to give point and direction to his own, is equivalent to the breaking down of those barriers of class, race, and national territory which kept men from perceiving the full import of their activity. . . These more numerous and more varied points of contact denote a greater diversity of stimuli to which an individual has to respond: They 
consequently put a premium on variation in his action. They secure a liberation of powers which remain suppressed as long as the inclinations to action are partial, as they must be in a group which in its exclusiveness shuts out many interests. - - A society which is mobile, which is full of channels for the distribution of a change occurring anywhere, must see to it that its members are educated to personal initiative and adaptability. Otherwise, they will be overwhelmed by the changes in which they are caught and whose significance or connections they do not perceive. 20

Dewey wrote that a democratic society is thus conmitted to change, organized as intelligently and as scientifically as possible. This society must be, in Dewey's words, "intentionally progressive." What more suitable theory for a society in flux, a society of immigrant and ethnic groups engaged in a convulsive transformation of customs and allegiances, a society whose philosophers have sensed a loss of community and the pressing urge to rebuild it? 21

Dewey believed that education had been used to keep certain classes stationed in the same place. The rich, he argued, had access to an intellectual, liberal education which gave them the tools to maintain their place in society. Iikewise they had access to the cultural, "uplifting," aspects of society. In a generally democratic society, he believed, education had to facilitate the democratic process of living together. Democracy (through education)

is an associated method of living together in such a way as to break down the barriers which separate the class which works with its hands from the class which occupies itself with matters of the mind.

However, reform of education was only one step along a road that had to go much further if reform was to be meaningful. "Social institutions, the trend of occupations, the pattern of social arrangements, are the finally controlling influences in shaping minds." 22 
Dewey's distrust of established interests led him to a highly critical analysis of industrial education. Dewey viewed the trend toward manual training merely as an attempt by industrial leaders to reinforce their own position at the expense of the laboring classes. Some of Dewey's progressive contemporaries, recognizing that there was not adequate room at the top for everyone, saw the industrial arts as the avenue for a secure and comfortable life for those engulfed in poverty:

When industrial interests began to demand special trade schools for the training of skilled workmen he was the first to sound the alarm. Educators, he declared, must insist upon the primacy of educational as opposed to mere industrial values, because the educational values represent the more fundamental interests of a society organized on a democratic basis.23

Dewey could not endorse a curriculum which did not further the growth, both mental and moral, of everyone in the group.

While other educators were content to interpret education as having rather precise ends, Dewey was always moving from the particular to the cosmic. The ends of education were not a particular lifestyle or the acceptance of certain moral precepts; rather, education and morals were one and the same:

There is an old saying to the effect that it is not enough for a man to be good; he must be good for something. The something for which a man must be good is capacity to live as a social member so that what he gets from living with others balances with what he contributes. 24

Dewey believed that what a man gives and gets were more than external possessions. A man must receive a widening and deepening of the conscious life.

Discipline, culture, social efficiency, personal refinement, improvement of character are but phases of the growth of capacity nobly to share in such a balanced experience. And education 
is not mere means to such a life. Education is such a life. To maintain capacity for such education is the essence of morals. For conscious life is a continual beginning afresh. 25

In the end Dewey felt that education must not separate the student from any aspect of life. Education must utilize the material of typical social situations.

For under such conditions, the school becomes itself a form of social life, a miniature community and one in close interaction with other modes of associated experience beyond school walls. All education which develops power to share effectively in social life is moral. It forms a character which not only does the particular deed socially necessary but one which is interested in that continuous readjustment which is essential to growth. Interest in learning from all the contacts of life is the essential moral interest. 26

Dewey's approach to education is based on the twin concepts of experimentalism and instrumentalism. To Dewey no institution in human life has reached any state of finality but instead all aspects of human life were in the process of becoming. Dewey was unwilling to formulate unequivocally and finally the means for achieving democracy in America. He felt that the quest for certainty led to mistaken and barren assurances.

In much the same way as Mann based his thinking on phrenology, Dewey adopted a doctrine of habit in which the mind was divided into conflicting impulses and desires. Thus the human mind, being formative and dynamic, could adopt new habits and modify old ones. Capitalism and democracy are habits which can be changed, and have no separate existence outside the human sphere. Democracy is therefore far more than an expression of popular sovereignty, it is a way of living together in which the class barriers that separate people from one another are broken down. Curti observes that, 
If the reconstruction of habits be systematically pursued in a new type of education, then the class codes of morals which, under the caption of ideals, sanction the status quo would be, according to Dewey, criticized and finally eliminated; new and more democratic habits, based on the same impulses, would arise. 27

Thus social class became Dewey's primary target. Class is an arbitrary power which prevents the equal opportunity for endless growth. Aristocracy, then, is particularly responsible for preventing universal goals because it is based on the sanctions of the past. Firmly rooted in his own era, Dewey was able to reach back into the past and extend into the future. He denied that education prepared people for external goals but instead saw it as a shaping experience which extended throughout life. Nor did he view the past as a lesson for the future. As Oscar Handin said of Dewey,

He directed his revolt not against tradition but against a rather recent development--the gap created by the inability of Americans to adjust their conceptions of education and culture to the terms of the changing world about them.28

As Rush Welter noted,

He was a representative man of his times because education was still the representative American political device, and (for all its complexity and sophistication) his thought summed up the thought of the progressives. 29

The concept of the common school, developed in the colonial period, was refined by men such as Mann and Barnard, and reached its fullest statement with John Dewey. It is important to note that the idea of class as found in the writing of these men is regarded as divisive, and destructive of the nation's highest aspirations. However, with the weapon of education they hoped to eradicate the effects of stratified society. They firmly believed that given the proper 
opportunity the common school would be instrumental in creating an harmonious society. With the Oregon School Bill of 1922 an ancient tradition came to its fullest fruition. 


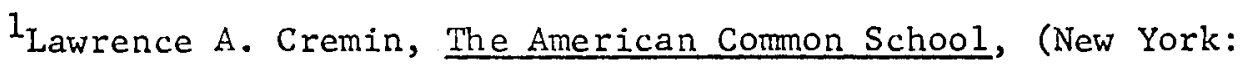
Columbia University Press, 1951), p. 28.

${ }^{2}$ Cremin, p. 221 .

${ }^{3}$ Cremin, p. 81 .

${ }^{4}$ Horace Mann, The Republic and the School, edited by I. A. Cremin, (New York: Teachers College, Columbia University, 1957), p. 59.

5Iawrence A. Cremin, The Transformation of the School, (New York: Alfred A. Knopf, 1961), p. 119.

6erle Curti, The Social Ideas of American Educators, (Patterson: Pageant Books, 1959), p. 126.

${ }^{7}$ Cremin, The Transformation of the School, p. 12 .

${ }^{8}$ Mann, p. 87 .

${ }^{9}$ Cremin, The American Common School, p. 24.

${ }^{10}$ Curti, p. 132 .

${ }^{11}$ Curti, p. 139 .

${ }^{12}$ I have no idea how he reconciled this with his conservatism. Apparently he was under no obligation to make his thinking consistent.

13 Curti, p. 149.

${ }^{14}$ Curti, p. 148 .

${ }^{15}$ Curti, p. 147 .

${ }^{16}$ Cremin, The Transformation of the School, p. 121.

17 Jo Ann Boydston, Guide to the Works of John Dewey, (Carbondale: Southern Illinois Press, 1970), p. 137. 
FOOTNOTES, CONT.

${ }^{18}$ Cremin, Transformation of the School, p. 121 .

19 Boydston, p. 136.

${ }^{20}$ Curti, p. 519.

${ }^{21}$ Curti, p. 505.

${ }^{22}$ Curti, p. 529.

${ }^{23}$ Curti, p. 523.

24 John Dewey, Democracy and Education, (New York: The Macmillan Company, 1916), p. 417 .

25 Dewey, p. 418.

${ }^{26}$ Dewey, p. 420 .

27 Curti, p. 250 .

28 oscar Handlin, John Dewey's Challenge to Education, (New York: Harper and Brothers, 1959), p. 48.

${ }^{29}$ Rush Welter, Popular Education and Democratic Thought, (New York: Columbia University Press, 1962), p. 279. 
CHAPTER III

THE CAMPAIGN FOR THE OREGON SCHOOL BILL

The Oregon School Bill of 1922 required all children between the ages of eight and sixteen to attend public schools for the entire school year. ${ }^{1}$ Although the history of the Bill after its introduction is quite clear, its precise origins are somewhat obscure. Initiated by a group of men from various cities throughout the state and supported by the Scottish Rite Masons, the Bill was placed on the general election ballot in November of $1922 .^{2}$

The move was sponsored by the Scottish Rite Masons, the supreme council of which had the petitions passed out quietly to various lodge and patriotic organizations throughout Oregon. Men from these organizations flashed the petitions suddenly at 8 o'clock Thursday morning (June 20, 1922) and the public literally lined up to sign. [The next day] with pcartically [sic] complete 50,000 signatures had been secured. ${ }^{3}$

Only 13,000 signatures were necessary to place the Bill on the ballot. In the next few weeks it became apparent that the proponents of the Bill had not received as many signatures as they had first announced and that certain irregularities had developed in the collection of signatures.

The Scottish $\mathrm{Ku}$ Kluxers who have charge of the antiCatholic school bill announced a month ago that in a whirlwind campaign of one day, they had secured 50,000 signatures for their petitions. It appears that their whole campaign had netted them fewer than 19,000 signatures. This is about as near as they got to the truth in the usual run of their pronouncements. 4 
In the early twenties initiative petitions were circulated by professionals who were required to be notary publics. Apparently some voters were not accurately informed regarding the petitions they were signing.

Others of the signatures are of persons who, it is averred, have no existence. Some of the voters' names appear twice on the same petition, and, according to the complaint, still others were minors, aliens or residents of other states.5

From the beginning the purposes of the Bill were quite clear. "The passage of this measure would wipe out of existence every military academy, denominational school or private school of any kind in the state, where pupils of grammar school age are taught." The Bill also provided that English be the only language taught in the grammar schools. The Bill was not to take effect until September of 1926; the delay was intended to "allow the private schools to close up their affairs." 6

Robert F. Smith, an early advocate of the Bill, said that it was designed to perpetuate American institutions. Once successful in Oregon, the Bill's sponsors intended to later carry the Bill to other parts of the nation. It was not so much that there was a clear and pressing danger, but that foreign elements had been "lethargic" in pursuing the war effort. 7

The official argument favoring the Bill appeared in several publications shortly after the petition drive and also appeared on the ballot in the Fall. Of the men submitting the argument none came from Oregon's largest cities. Most were from eastern Oregon or the southern Willamette Valley. ${ }^{8}$ 
The proponents of the Bill claimed that the best interests of all citizens in the nation were served by the common school. 9

What is the purpose of our public schools and why should we tax ourselves for their support? Because they are the creators of true citizens by common education, which teaches those ideals and standards upon which our government rests.

The School Bill would prevent ethnic groups from fostering antagonism to the principles of American government and would also forge all nationalities and classes into one.

Mix the children of the foreign born with the native born, and the rich with the poor. Mix those with prejudices in the public school melting pot for a few years while their minds are plastic, and finally bring out the finished product-a true American. 10

Our children must not under any pretext, be it based upon money, creed or social status, be didved $[\mathrm{s} i \bar{c}$ ] into antagonistic groups, there to absorb the narrow views of life as they are taught. If they are so divided, we will find our citizenship composed and made up of cliques, cults and factions, each striving, not for the good of the whole, but for the supremacy of themselves. A divided nation can no more succeed than a divided school.11

The men who submitted the Bill were all members of the Shrine. Throughout their arguments they imply that support of this Bill is also support of the school system, and conversely that to denounce the Bill is to repudiate the school system. The proponents of the Bill saw the Bill as 1) facilitating the assimilation of ethnic groups, 2) furthering American principles and traditions, 3) making the school system more efficient and 4) ameliorating divisions among citizens of the nation.

The months before the general election of 1922 were marked by heated controversy over the School Bill. A broad range of arguments can be found favoring the Bill, as well as a broad range of people 
offering these arguments. The affirmative arguments generally fall into two areas. The first could be described as progressive because they seem to be based on the tenents of progressive education. In this category would be arguments stating that the schoolroom must be a melting pot, and that in general education must be made more efficient and systematic. The second group of arguments is based on fear and paranoia. Included here are statements that ethnic groups did not fully support the war, and that Catholics placed allegiance to the Pope instead of the American nation. The progressive arguments were more in front of the public's eye and were more cohesive. While the paranoid arguments were present, they seemed to remain on the fringes. In an era of fewer media, citizens depended on the newspapers and public meetings for information. Groups taking a stand on the Oregon School Bill used these two methods in bringing their message to the public. The Masons, the primary group supporting the Bill, had several speakers touring the state and also had several newspaper advertisements which they had printed throughout the state. Nearly every community had its own newspaper in 1922.

Some ads seemed to sumarize all of the arguments favoring the Bill. "Vote 314 yes and have free public schools... open to all, good enough for all and attended by all . . all for the public school and the public school for all . . one flag, one school, one language." 12 One advertisement noted that because there were few private schools, the transition to all public education would be easy. "Surely if the public schools are good enough for the 131,689 they are also good enough for the other 9,841." Nearly all of these ads 
mentioned the possibility of higher school costs, but passed this eventuality off as being "nominal."

Now is the time to pass this measure, insuring that in Oregon all of our children will be educated to a common patriotism, common ideals and a unified allegiance to our institutions.13

As in the question of additional costs, the issue of religious freedom is played down.

This bill proposes no religious restrictions. It contemplates no limitation of the right of the parent to teach religion to his child in his own way and according to his own belief. It raises no issue of religious difference. 14

A Portland paper reported that "The issue presented is not an issue of religious creed or factionalism or intolerance. It is an issue of true American progress."15 Always present was the fear that those who did not seem to be working for the nation were working against it.

Ignorance of American ideals and institutions and language is the greatest menace to them, because those who do not understand them properly do not support them.16

Supporters of the Bill tapped many sources to show their side in a favorable light. One advertisement was called "the Test of Good Citizenship" and was taken from the Hearst Sunday papers. Money going to schools was an investment in the future which paid off handsomely, the ad stated. Further, it argued:

The test of the politician, the office holder, is his attitude toward the public school. If he hesitates, if he departs one inch from the old idea that the PUBLIC school is the school of America, and the ONLY school; if he hesitates in his loyalty to that school, he is a traitor to the spirit of the United States, and your vote should tell him so.

The public school is the United States in miniature. In it the little citizens that are to be the future voters sit side by side, aII EQUAI. They study and learn to know each other. They realize--most precious knowledge--in early youth that it is what YOU ARE, not what your father HAS or what your grandfather WAS, that makes the difference in the world. 
The ad concluded by stating a vote favoring the Bill was a vote for "even-tempered progress."17 Information from this ad was also used in widely distributed pamphlets.

Nor were the proponents of the Bill averse to drawing on the social ideas of Theodore Roosevelt:

We stand unalterably in favor of the public school system in its entirety. - . We are against any recognition whatever by the state in any form of state aided parochial schools. 18

Many of the ads merely quoted from the basic affirmative argument offered at the beginning which appeared on the ballot and on the petitions. In other cases the ad merely borrowed the ideas.

No debate before the public would be complete without calling upon the Puritan forefathers. The public schools were "a principle laid down in Massachusetts Bay Colony in 1647." The ad pointed out that public education supervised by the state has been an American tradition.

Thus our forefathers foresaw, with that rare wisdom which marked their deliberations generally, that education of American youth in the public schools was a necessary means to the end of moulding an elightned [sic] citizenry and through it perpetuating the growth and development of American institutions.

The ad concluded by stating that a vote for the School Bill was "a vote for a unified nation."19

Whether the ad was placed by a private group such as the Scottish Rite Masons or by a public schools' committee in a town it invariably noted that in the public school children from widely diversified backgrounds mingled together.

The American public school is a democratic institution. It puts love of equality into the hearts of men. It breeds faith and confidence in them because mingling with all classes brings 
the kind of fellowship which makes national leadership a positive thing. To isolate the growing child and to deny him of his comradeship is a thrust at the very life of the nation. It breeds class distinction, the most demoralizing and deadly force which undermines the spirit of any great people. 20

The public school was the "cradle of the nation's future greatness."21

Editorials in Portland's newspapers do not reveal as much as one might hope regarding the School Bill. Of the three major daily papers the Telegram was very firmly against the Bill, while the positions of the Oregonian and the Journal were somewhat equivocal. In the weeks before the election the Telegram minced no words in stating that its editors regarded the School Bill as depriving the people of their rights and as supported by a hate-filled organization. The Journal and Oregonian attempted to describe both sides of the issue and present sufficient material to permit the voter to make an intelligent decision for himself. ${ }^{22}$ One rural Oregon paper noted that the two papers were against the Bill, but added that neither did anything to defeat it. ${ }^{23}$ Similar to the position of the Portland papers, initially the teachers of Oregon could not seem to reach any sort of clear position. Although the Oregon Teachers Monthly took a strong stand supporting the measure, there is very little other evidence concerning the feelings of teachers toward the Bill. Perhaps because of their tradition of servility in this period, teachers did not feel it was their place to campaign in a public political question. 24

Recognizing the very controversial nature of the Bill, the first time the Monthly dealt with the Bill it was indirect in its approval:

It is a measure to put all Americans under exactly the same nationalizing influence--the public school--that should be the leavening power for American progress. It aims to make the democracy of the public school an antidote for the inevitable 
class consciousness and possibly lopsided or snobbish private school attitude. It aims to teach every child the same fundamentals of equality, of historic development, of ethics; so that there shall be no classes, no unassimilable groups trained from childhood to other than the common teachings of Americanism.

The editorial goes on to remind the reader that some of the most feared and hated men in American history such as greedy industrialists or unprincipled politicians did not have the benefit of a public school education. Even President Roosevelt had sent his children to public schools because he knew "there was no other source for good Americanism." 25

The editorial concludes by dealing with the critics of the School Bill and suggesting that the teacher treat the entire matter with caution.

Reduced to its ultimate logic, most of the argument against the new educational bill is a direct or implied arraignment of the public schools as incompetent or incomplete. If the measure sought to deprive the child of all home training, or of all moral teaching, it would indeed be a menace.

Teachers were not, at this point at least, ready to endorse the Bill, yet they seemed to see the Bills' attackers as challenging their own work.

The second time the Oregon Teachers Monthly dealt with the Bill it was far more direct in its treatment. The writer of this article said the "real issue" was this:

Shall all our children, up to, and including, the eighth grade, do this work on a common level of neighborliness; or shall they be divided into a number of selfish and exclusive clans? Shall those of one blood have no association with those of another blood? Shall those whose parents prefer a particular form of religion be taught that they must not be friends with those outside their circle? 
The writer goes on to say that the desired results of education are far more than simply imparting knowledge.

We want a citizen body that is not divided into parties by any of the old world notions, prejudices or passions, a citizen body in which all are interested for the welfare of each--and each for all. We want all the citizens to be neighbors and co-workers for the welfare of America, our country. 26

One problem which caused difficulty for the proponents of the Bill was that of religion. Public schools taught religion as surely as did any parochial school, but the difference was that the public school taught "morality not sectarianism."

True they do not teach sectarian notions; but not even the best non-public schools can surpass them in teaching and enforcing upon all those principles that are claimed by the sectarian objector.

In conclusion the editorial noted that New York statistics showed that "the parish school furnishes, per thousand of population, three to four times as many criminals as the public school class."

The writer repeated many of the arguments used by other proponents of the Bill without explicitly recommending that teachers vote for it. Part of his motivation seemed to be that the measure represented a vote of confidence and that failure of passage showed an incompetent school system. Possibly the writer had inner misgivings about the Bill, but feared that detractors of the School Bill seemed to be attacking the existing school system.

We need but the one system of primary schools that, in one language, shall train all the children of our country to become worthy citizens respecting the authority of our nation and the equal rights of all people of the land.

The editors of the Teachers Monthly, like the other proponents of the Oregon School Bill, based their endorsement on precepts already 
deeply rooted in the American imagination. While there were vitriolic outbursts by some men, there were none of the violent episodes one would expect if nativism were rampant. Drawing on the ideas of Mann and Dewey, perhaps unconsciously, the champions of the Bill appealed to the voters in familiar terms. Students, as well as society, would benefit from a school system which gave all children an equal start. The voters of Oregon saw class awareness as an enemy of democratic institutions. They chose the common school approach to strengthen the nation and unite its people. The voters of Oregon took their cues, not from the leaders of the Klan or the Masons, but from America's most venerable educators. 


\section{FOOTNOTES}

${ }^{1}$ Ancient Order of Hibernians, The Oregon School Fight, (Portland: A. B. Cain, 1924), p. 3.

2 The precise origins of the Bill are clouded, perhaps because of the secret nature of the groups supporting the measure.

$3_{\text {The Torch, July 15, 1922, p. } 1 .}$

${ }^{4}$ Loose clipping, dated July 27, 1922.

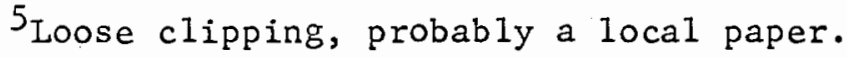

${ }^{6}$ The Torch, July 15, 1922.

$7_{\text {The Torch, July } 15,1922 .}$

8 Hibernians, p. 3 .

${ }^{9}$ The terms common school and public school were used interchangeably.

${ }^{10}$ Oregon Voter, July 22,1922, p. 7.

${ }^{11}$ Oregon Voter, $p$. 7-8.

12 Eugene Register Guard, November 4, 1922.

13 Stanfield, Oregon Standard, October 27, 1922. This ad, like several others used here, appeared unchanged in newspapers throughout the state.

${ }^{14}$ Dufur, Oregon Dispatch, October 19, 1922.

15 Portland News, September 9, 1922.

${ }^{16}$ Dufur Dispatch, October 19, 1922.

${ }^{17}$ Portland Journal, October 25, 1922.

18 Grants Pass Courier, October 26, 1922. Ironically enough, both sides drew on the wisdom of $T$. $R$. in presenting their respective cases to the public. 
FOOTNOTES, CONT.

${ }^{19}$ Springfield, Oregon News, October 26, 1922.

20 Portland Oregonian, October 22, 1922.

21 Portland Telegram, October 31, 1922.

${ }^{22}$ See the Oregonian on October 30 and 31 , as well as November 1 , 2 and 3. Likewise in the Journal see October 22, 26 and 28 . Because of the prestige of organizations such as the Masons, these two papers hesitated to antagonize members of the community. However, it is also possible that the staffs of the two respective papers were sufficiently divided that no consensus could be reached.

23 Dallas, Oregon Observer, November 2, 1922.

24 Tyack cited no evidence on the position of teachers concerning the Bill.

25 Editorial, Oregon Teachers Monthly, October, 1922, p. 12.

${ }^{26}$ Editorial, Oregon Teachers Monthly, November, 1922, p. 16. 
COURT REVIEW AND REJECTION

Much like the Ku Klux Klan in Oregon after 1924, the Oregon School Law met an early and ignominious death. For both, it was all over by 1925 . In that year membership in the Klan steadily waned and the School Bill's unconstitutionality was confirmed by the United States Supreme Court.

After the successful initiative petition drive during the early summer of 1922, the Bill requiring all school age children to attend public schools was placed on the general election ballot for November 7, 1922. Interest in the election centered on this measure and on the race for governor. The Compulsory School Bill was passed by a vote of 115,506 to 103,685 , giving those in favor of the Bill a

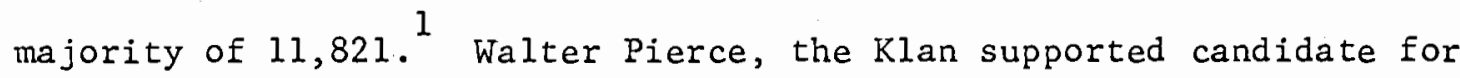
governor, was elected by 133,392 votes to 99,164 . The fact that Pierce won so handily was expected, despite the 238,444 to 89,477 margin of registered Republicans to Democrats. Pierce's victory was largely due to his promise to ease high taxes and provide relief from hard times. Contemporary accounts maintained that Pierce lost as many votes as he won by endorsing the School Bill. 2 In any event the results show something of a turnabout in Oregon politics.

The distribution of votes reveals the sources of support for the School Bill, which seems to have come primarily from the cities. 
Despite the fact that the measure did pass, twenty-one of Oregon's thirty-six counties voted the measure down. ${ }^{3}$ As Janet Bryant observed,

It is interesting to note that Marion County, in which the Salem Capitol-Journal continually battered the Klan and its School Bill, voted the Bill down, even though it housed a relatively large city. Althougl Jackson and Klamath Counties were the scene of the First Klan organizations, which were relatively strong, by the time of the Fall of 1922 there was equally strong organized opposition to the Klan, with the, Medford Mail Tribune and Klamath Herald in the forefront. 4

The triumph of the School Bill was especially noticeable in Portland where it piled up two thirds of its victory margin. 5 The School Bill won by a great majority in urbanized Multnomah County $(6,124)$, and in urbanized Lane County $(4,655)$. In Clackamas County, an adjunct of Multnomah County, the Bill passed vith a majority of 1,380 . The Portland Oregonian on November 8, 1922, in an article entitled "lead of Pierce 2,542 in County" had an interesting comment about the election:

Not since women were given the ballot in Oregon have so many attended the polls in Multnomah County as yesterday. The women were aroused by the religious issue and the school bill. They flocked to the polls in platoons, battalions and regiments. . .

Charles Easton Rothwell argues that the women's vote was quite important in passage of the School Bill. Rothwell states that because women were more receptive than men to fundamentalist religious doctrines, ${ }^{6}$ they tended to vote for the Bill.

It is also interesting to note the attitude assumed by the Klan after the passage of the compulsory school law. Recognizing the need for the help of other "patriotic" organizations in the struggle to bring similar school laws to other states, the Klan was careful to give credit to all who had contributed to the passage of the Bill. 7 The 
November 30,1922 , issue of the Western American brought forth the view that the Masons should also be credited for their aid in "the great victory."

It was backed, of course, by patriotic societies in general and by the Ku Klux Klan in particular, the great Klan being consecrated to Liberty and devoted to the educational work of which the Public School Bill is a part. It was foolish and preposterous to claim that "the Klan did it," and no true Klansman will make such a boast. 8

The Klan recognized the need for solidarity with like-minded groups even in the moment of its "greatest triumph."

After passage of the Bill, representatives of private and parochial schools gathered to plan strategy against the newly passed law. In January of 1924, Hill Military Academy and the Society of Sisters of the Holy Names of Jesus and Mary filed bills of complaint against the various authorities whose responsibility it would be to enforce the new land and Governor Pierce. Both groups alleged similar damages. They argued that the new law was unconstitutional because it amounted to seizure of property without due process of 1 aw. They also alleged that it was an illegal restriction of the rights of parents and teachers, and that it was a violation of the state laws of incorporation. 9 On March 31, 1924, the U.S. District Court found in favor of the private schools and issued an injunction preventing the law from being enforced.

The text of the decision in which the Oregon compulsory school law is declared unconstitutional is, of course, couched in legal arguments and jargon. In dealing with the law, Judges Gilbert, Wolverton and Bean responded to the arguments presented by the lawyers for both sides who had substantiated each of their points with appropriate 
precedents. After establishing the jurisdiction of the court and the right of the plaintiffs to bring the case asking for an injunction against the law, the court dealt with the question of property rights. The court concluded that property rights would be violated by the new law and it would also hinder the plaintiffs' constitutional right to pursue an occupation. Thus private schools would lose patronage as well as burdened with unusable buildings and equipment. 10

Much of the decision deals with the time element. Was it necessary for the private schools to bring the suit so soon and was it proper to set the date in which the bill was to go into effect so far ahead? The court responded affirmatively in both cases.

The most important part of the text dealt with the proper powers of the state.

- - But there is a limit to the manner in which these powers may be exercised by the state. They cannot be exercised arbitrarily and despotically, nor unless there exists a reasonable relation between the character of the legislation and the policy to be subserved. Nor is the state legislature the final judge of the Iimitations of the police power. Its enactments will be set aside when found to be unwarranted and arbitrary interference with rights protected by the constitution in carrying on a lawful business or occupation in the use and enjoyment of property.il

The court upheld the power of the state to regulate education, but said that it could do so only in a lawful manner.

The court noted that the state already had an effective compulsory education law and that the Bill in contention was not necessary. Nor did the court go along with the rhetoric favoring the concept of the common school.

The melting pot idea applied to the common schools of the state, as an incentive for the adoption of the act, is an extravagance in simile. A careful analysis of the attendance of 
children of school age, foreign born and of foreign parentage, at private schools, as compared with the whole attendance at schools, public or private, would undoubtedly show that the number is negligible, and the assimilation problem could afford no reasonable basis for the adoption of the measure. But if it be that the incentive is political, and arises out of war exigencies and conditions following thereupon, then the assimilation idea is pointedly answered by the opinion rendered in the Meyer case:

The desire of the legislature to foster a homogeneous people with American ideals prepared readily to understand current discussions of civic matters is easy to appreciate. Unfortunate experiences during the late war and aversion toward every characteristic of truculent adversaries were certainly enough to quicken that aspiration. But the means adopted, we think, exceed the limitations upon the power of the state and conflict with rights assured the plaintiff in error.

So it is here, in our opinion, the state acting in its legislative capacity has, in the means adopted, exceeded the limitations of its powers--its purpose being to take utterly away from complaintants their constitutional right and privilege to teach in the gramnar grades--and has and will deprive them of their property without due process of law.12

The reaction to the court's decision was fairly predictable.

Groups favoring the Bill stated that they would continue to fight for the measure through a series of appeals in the court system. Groups which had been against the Bill were satisfied that justice had been properly served by the three man court. Newspapers were not surprised about the results of the court case: the possibility that the Bill would be held unconstitutional had been present throughout the campaign. Hence the decision came as an anti-climax. Interest in the Bill seems to have waned before the courts had decided its ultimate fate.

The Portland Telegram, against the Bill from the very beginning, seemed to echo the thoughts of Horace Mann in commenting on the court's decision.

Now that it may be found unconstitutional to compel the attendance of all children in primary public schools the very important thing remaining to do is to make our public schools so efficient that they will compel attendance by their 
attractive superiority. To a degree at least our public schools have already accomplished this end. Private schools have actually been starved out by fair competition in numerous instances.

The editorial went on to state that what remained to be done in the field of education was to recruit qualified teachers. The school district could buy good equipment and create a positive atmosphere, but it was the capable teacher who made the difference. "We could well afford to make teaching a more attractive profession. Is any work more important in its bearing on the future of America?"13

The Portland Journal reflected some of the same sentiments but emphasized that the fate of the Bill was never really in doubt.

The decision in the compulsory school case is not a surprise. It is what a great many people expected. Looking backward, the wonder is that there should have been so much bitterness in the campaign when the bill was pending.

The editorial expressed confidence in the judicial system and the ability of that system to bring an orderly conclusion to the controversy. "This is a country in which there is always a legal remedy. It is the great redeeming factor in the American system." The editorial concluded by noting the amount of work yet to be done. It stated there were many people still who could not read or write English.

Facing such a responsibility, committing to the ballot the issue of whether or not this greatest experiment in self government is to succeed or fail, can we afford to lock the door of any schoolhouse?14

The Portland Oregonian stated that the decision had been expected, commended the court for a learned statement of law and noted that it had come in plenty of time for the schools concerned to chart their future. 
An outstanding merit of the decision just made is that it is a frank, learned and convincing discussion of all phases of the case, a complete apprehension of the fundamental issues, a distinct purpose to postpone or evade nothing. It is the law as the court saw; and the court expounded the law.

The Orcgonian saw no reason for the United States Supreme Court to alter the lower court's decision, nor waste any time bringing the case to that court. "It is to the interest of all concerned that the whole question be passed with all expedition to ultimate decision by final authority."15

The Portland Daily News carried quotations from several of the lawyers and judges involved in the case.

Nothing has been taken away from the public schools and will be put into them as a result of the federal decision relating to Oregon's compulsory law, John Veath, who represented the Hill Military Academy, chief plaintiff, said Monday following his victory.

The state is restrained from acting against private and parochial schools, and they may proceed unmolested.

The News also had a statement by J.P. Kavanaugh who represented the Catholic institutions involved.

Of course, it is subject to review, but it means that private schools will continue free from laws intended for their destruction. The law was in violation of the 14th Amendment in the Constitution intended to protect life, liberty and property. All agitation and bitterness should now stop.

Although the results of the court decision would be appealed, most men assumed that the ultimate fate of the Bill had been decided. ${ }^{16}$

Of course, the Ku Klux Klan was quite disappointed in the results. While it expressed confidence that the United States Supreme Court would reverse the lower courts, it was surprisingly amenable to interpretations through the judicial process. In the Western American, spokesmen for the Klan commented: 
In the meantime the enemies of this piece of legislation will make the most of it and are at liberty to do so as far as we are concerned. We feel as we always felt and still think as we thought before. It is by a most laborious process that a reform for the good of all people is brought about. "Selfpreservation is the first law of nature," and we still believe that the first duty of a democracy is self-preservation of itself through the enforced education of the multitude of individuals of which it is composed. By the enemies of the school bill we do not mean the Roman Catholic layman. There are many such who think they are, but time will show them that this law is to the advantage of any good American citizen and only to the disadvantage of autocracy, political and ecclesiastical.

The article continues in the same vein.

If the American people find that their constitution gives an ascendancy of property rights over human rights as would be shown by an adverse decision on this bill by the Supreme Court of these united States, then they will change the constitution. Remember, "Time and events may stand for a time between you and justice, but it is only a postponement" and "things refuse to be mismanaged long." 17

It must be some form of ultimate twist of irony that a group such as the Klan could question the placing of property rights over human rights, but in the legal arguments this is, of course, what the courts had done. It is surprising that the Klan could take the decision so calmly. Perhaps this merely reflects the Klan's interest in maintaining its image as a respectable and law-abiding fraternal organization. In these passages the vitriolic attitude which one expects from the Klan is simply not present.

likewise the language in the Catholic Sentinel is quite muted.

The decision repudiated the argument of the defendant officials that the measure was merely regulatory in character, declaring, on the contrary, that it aimed at the destruction of the complainant's grade schools and was therefore beyond the competence of the state to enact and not essential for the proper enforcement of the state's school policy.

The article goes on to point out that much of the case against the Bill 
was derived from the work of Catholic scholars and writers from the middle ages down to the present.

It is fitting that a great principle of jurisprudence, hammered into shape in Catholic schools in ages past, should be used by the courts of the land as a protecting shield for the Catholic schools of today.

The point really in contention throughout this entire matter was the role of the state in private lives.

The state's power over institutions which it supports is one thing and its power over institutions supported by others is quite another thing in the opinion of the supreme court which went on to say that the attempt to prevent a private school from teaching a foreign language was beyond the competence of the state.18

From the District Court the Pierce Case went to the U. S. Supreme Court. On June 1, 1925, the Justices unanimously upheld the lower court and noted that the state had no right to "standardize its children by forcing them to accept instruction from public school teachers only." The Bill was rendered null and void over a year before it was to have taken effect. ${ }^{19}$

While Catholics and other private school interests rejoiced in the sagacity of the courts, the champions of the School Bill attempted to regroup and renew their efforts. In all, few people were surprised by the decisions of the courts. The voters of Oregon recognized that other ways had to be found for improving the schools and the rest of society. In declaring the measure unconstitutional the courts passed judgment on an ancient segment of American mythology. While the motives of the proponents of the Bill might be honorable, the courts stated, there were 1 imits to what society could ask of the schools. Society would have to $100 \mathrm{k}$ elsewhere for solutions to its problems. 
CHAPTER IV

FOOTNOTES

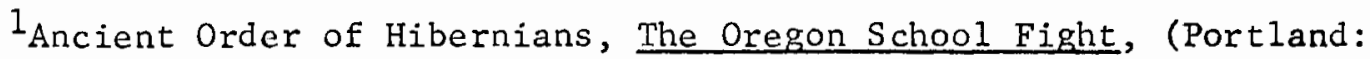
A. B. Cain, 1924), p. 3 .

${ }^{2}$ Oregon Voter, November 11, 1922, pp. 4-5.

3 Portland Telegram, November 9, 1922.

${ }^{4}$ Janet Bryant, "The Ku Klux Klan and the Oregon Compulsory School Bill," (unpublished M.A.T. thesis, Reed College, 1970), p. 129.

5 Kenneth Jackson, The Ku Klux Klan in the City, (New York: Oxford University Press, 1967), p. 207.

${ }^{6} \mathrm{C}$. E. Rothwell, "The Ku Klux Klan in the State of Oregon," (unpublished senior thesis, Reed College, 1924), p. 134.

${ }^{7}$ Bryant, p. 132 .

8 Western American, November 30,1922, p. 3 .

${ }^{9}$ Portland Oregonian, August 23, 1923, p. 3.

$10_{\text {Hibernians, p. } 14 .}$

$11_{\text {Hibernians, p. } 139 .}$

12 Hibernians, p. 43.

13 Portland Telegram, April 3, 1924, p. 4.

${ }^{14}$ Portland Journal, April 2, 1924.

1.5 Portland Oregonian, April 3, 1924.

16 Portland Daily News, March 31, 1924.

17 Hibernians, p. 50.

${ }^{18}$ Catholic Sentinel, April 3, 1924.

19 David Tyack, "The Perils of Pluralism," American Historical Review, LXX (October, 1968), p. 78. 
CHAPTER V

CONCLUSION

The citizens of Oregon seem to have lost interest in the School Bill even before the United States Supreme Court declared it to be unconstitutional. After the election, and especially after the decision of the District Court, newspapers seemed to ignore the Bill. Perhaps this was due to the long lead time before the measure was to take effect. More importantly, the Oregonian had suggested from the start that the Bill would be declared unconstitutional and the District Court decision proved it. In all, the events following the Fall election of 1922 proved to be anti-climactic.

The measure appeared rather suddenly in Oregon and perhaps the state's citizens did not take ample time to consider it. While the Bill was part of an ancient tradition, there seemed to be a nagging doubt after the election whether a nineteenth century concept was applicable in the twentieth century. Mann and Barnard had come up with a very American and very democratic approach to mastering the exigencies of a changing world, but it was founded on the assumption that society ought to be homogeneous. John Dewey certainly endorsed the concept of a common school, but he was unable to endorse the measure in Oregon, and may have been against it. ${ }^{1}$ Given a longer time to consider their actions the citizens of Oregon seemed to sense that what was quite attractive in theory could not work in practice. 
One can only speculate concerning the role of educators and the Oregon School Bill. Of course, overtly the teaching profession had a very low profile in the campaign for the Bill. As we have seen, teachers did not take part in the direct campaign before the voters. However, they did seem to favor it in their own circles. Educators may have been responsible for the momentum of the Bill because they had a personal stake in the educational system and could not admit that schools alone were impotent to cure social disease. There seemed to be no gray area for educators, schools were the single best institution to reform society.

As we have also seen, educators interpreted attacks on the School Bill as direct attacks on the schools. They seemed to reason that if parents wanted to send their children to private schools then public schools were deemed to be somehow inadequate. (Educators sensed that they had been unable to build the irresistibly attractive school that Mann had described--the school that all parents would want their children to attend.) As Michael Katz has suggested, the education establishment "can become a vested interest in its own right, so pious and powerful that it can direct public scorn to anyone who doubts."2

It is important to remember that the $1920^{\prime} \mathrm{s}$ were formative years for education. It was during this time period that state Normal schools were being set up to train teachers. Schools of education, newsletters and exchanges of faculty members were all signs of a new and distinct field. However, the teachers and administrators of parochial schools did not come out of this tradition. Instead, they were trained in colleges of their own religion and were members of 
religious orders. Perhaps public school teachers harbored resentment toward educators whose experience was seemingly quite different than their own.

The concept of the common school, however, continued to be a part of educational thinking in Oregon. Long after the Oregon School Bill of 1922 was forgotten educational leaders continued to express their ideas in terns that would have been familiar to Mann and Barnard. The school continued to be a microcosm of society where children from a11 levels of society could meet and learn the lesson of democracy firsthand. The public school also continued to be a launching pad for social mobility. If nothing else, educators continued to see the school as the best single weapon that America had to combat its ills. The concept of the common school is found in the literature of education in 1936:

The greatest single factor in the development of an American type has been and still is the public schools. Here they come in contact with one another and learn to live and play together. If we are ever to become a united people as well as a United States, it can only be through an effective program on socialization and mutual understanding carried on in the public schools.3

Likewise, educational writing acknowledged that the school was the basis for the attainment of a better life.

It is a simple thing in Europe to say to a boy that he shall remain a peasant boy, of the peasant class, that is, it was a simple thing before our boys got across the water. But did you ever tell an American boy that he was born to be a hewer of wood, or a drawer of water, and that he should remain so?

In the end, according to the thinking of educators, the public school stood for equality. "Every American boy and girl shall belong to the only true aristocracy--that of achievement." 
While teachers may have been reluctant to enter the fray of controversy over the School Bill directly, they were able to consistently relate to the concept of the common school in history. "The only fundamental institution in America was that built at one of those little commons back in the frontier town." Yet in the end teachers were aware that they carried out public policy, but did not make it. "The American public school at present, whatever its virtues or defects, is the measure of public interest in the maintenance of American ideals. ${ }^{5}$

In reviewing our understanding of the Oregon School Bill it is also important to reexamine the role of the Klan. As we have seen, David Tyack and Janet Bryant attribute the success of the School Bill to the campaign waged by the Klan in its behalf. One cannot help but wonder, howevef, if the strength of the Klan has not been overestimated. Future scholarship ought to investigate that organization on the basis of evidence such as found below.

There is evidence that the $\mathrm{Klan}$ was not well received in the general community. At one Klan meeting in June of 1922 , it was necessary to send nearly 100 policemen, not to prevent Klan members from committing violence but to prevent hostile crowds from attacking Klan spokesmen. 6 Cicero Hogan, an ex-serviceman, warned the City Council that trouble was brewing. "Ex-servicemen of Jewish or foreign extraction or of Catholic faith have made threats he insisted. These men are all ex-servicemen who have proved they are 100 per cent Americans." There was also interest in public scrutiny of secret organizations. 
Because of the activities of certain secret organizations in Oregon, the legislature will be asked at its next session to enact legislation providing that the bylaws and membership of any secret organization, lodge or society shall be filed with the secretary of state. 7

Following the victory in Oregon the Klan intended to introduce compulsory public education in Washington in 1923. However, efforts through the legislature and through initiative petition drives failed to bring the measure to enactment. Like the people in her sister state, Oregon, many citizens of Washington were apprehensive about the appearance of the Klan. A bill was introduced in the Washington State Legislature which "makes it unlawful for any assemblage of three or more persons to be disguised by having their faces painted, discolored or covered such as to make such person unrecognizable. "8 The bill was not passed but its very appearance is significant. Other problems appeared with the Washington Klan. The January 26, 1923, issue of the Seattle S.tar carried the headline, "Nightgowns in Demand." It began its article on the Klan by stating

one order for 371 nighties and night caps was placed in Seattle last Wednesday, when that number of candidates was initiated into the mystic rites of the Knights of the Ku Klux Klan.

The Klan was, of course, not important in the Pacific Northwest after 1925. Men left as quickly as they had joined and we must conclude that its membership problems ran deeper than how to supply uniforms or whether it was against the law for men to disguise themselves. Likewise, the School Bill held little interest to citizens after 1925. The concept of the common school, however, continued to 
capture man's imagination. Through the 1930's and 1940's, evidence suggests, educators still believed that the strength of society was based on a homogenizing school system.

The drive for unity, therefore, did not spring from intolerance and bigotry as much as traditions from within the nation's educational theory. Neither the Klan nor the Masons were as responsible for the Oregon School Bill as were Horace Mann and John Dewey. Whether nativism was rampant during the early 1920's becomes less relevant. What is important, rather, is what the nation expected of its school systems, and what they had represented in the past. The drive for homogeneity in Oregon was the culmination of many years of development and refinement. 
CHAPTER V

FOOTNOTES

$1_{\text {David Tyack, "The Perils of Pluralism," American Historical }}$ Review, LXX (October, 1968), p. 82.

2 Michael Katz, The Irony of Early School Reform, (Boston: Beacon Press, 1968), p. 217.

${ }^{3}$ Portland Public Schools, Elementary Curriculum, (Portland: 1936), p. 24 .

${ }^{4}$ Portland Public Schools. The School Bulletin, (Portland: January, 1923), p. 17.

5 Ibid.

${ }^{6}$ Portland Telegram, May 10, 1922.

${ }^{7}$ Portland Journal, August $21,1922$.

${ }^{8}$ Spokane Washington Press, January 17, 1923. 


\section{A SELECTED BIBLIOGRAPHY}

\section{PRIMARY SOURCES}

Addams, Jane. Twenty Years at Hull House. 3rd edition. New York: The MacMillan Company, 1960.

Cleveland, Alfred A. "The Educational History of Astoria, Oregon." The Quarterly of the Oregon Historical Society, March 1903.

Dewey, John. Democracy and Education: An Introduction to the Philosophy of Education. New York: The MacMillan Company, 1920.

Dewey, John. Human Nature and Conduct. New York: The Modern Library, 1930.

Dewey, John. Lectures in the Philosophy of Education: 1899. Edited by Reginald Archambault. New York: Random House, 1960.

Dewey, John. The School and Society. 2nd edition. Chicago: The University of Chicago Press, 1926.

Mann, Horace. The Republic and the School: Horace Mann on the Education of Free Men. Edited by Lawrence A. Cremin. New York:

Teachers College, Columbia University, 1959.

Oregon Historical Society. "Nativism in Oregon," MSS 非33.

Oregon Historical Society. "The Lutheran Schools Committee," MSS 646.

Oregon Teachers Monthly. Editorial, October 27, 1922, p. 12.

Portland Public Schools. Elementary Curriculum. Portland, Oregon, September, 1936.

Portland Public Schools. The School Bulletin. Portland, Oregon, Vol. IX, No. 16, January 28, 1922, and Vol. XIII, No. 9, January 23, 1926. 
SECONDARY SOURCES

Ancient Order of Hibernians. The Oregon School Fight: A True and Complete History. Portland: A.B. Cain, 1924.

Baker, Melvin C. Eoundations of John Dewey's Educational Theory. New York: Atherton Press, 1966.

Bel1, Daniel, editor. The Radical Right: The New American Right. Garden City: Doubleday and Company, 1963.

Bible, Thomas William. "History of Early Common School Education in Washington." Unpublished Ph.D. dissertation, University of Washington, 1929.

Boydston, Jo Ann. Guide to the Works of John Dewey. Carbondale: Southern Illinois University Press, 1970.

Bryant, Janet K. "The Ku Klux Klan and the Oregon Compulsory School Bill." Unpublished M.A.T. thesis, Reed College, 1970.

Carpenter, Charles. History of American Schoolbooks. Philadelphia: University of Pennsylvania Press, 1963.

Constance, Clifford I. Chronology of Oregon Schools. Eugene: University of Oregon Books, 1960.

Corning, Howard M., and Powers, Alfred, editors. History of Education in Portland. W.P.A. Adult Education Project. Salem: State System of Higher Education, 1937.

Cremin, Lawrence A. The American Common School: An Historic Conception. New York: Columbia University Press, 1951.

Cremin, Lawrence A. The Transformation of the School: Progressivism in American Education, 1876-1957. New York: Alfred A. Knopf, 1961.

Curti, Merle. The Social Ideas of American Educators. Patterson: Pageant Books Incorporated, 1959.

Dix, Lester. A Charter for Progressive Education. New York: Columbia University Press, 1939.

Elson, Ruth. Guardians of a Tradition. Iincoln: University of Nebraska Press, 1964. 
Filler, Louis, editor. Horace Mann on the Cris is in Education. Yellow Springs: The Antioch Press, 1965.

Gellerman, William. The American Legion as Educator. New York: Teachers College, Columbia University, 1938.

Goldman, Eric F. Rendezvous with Destiny: A History of American Reform. New York: Vintage Books, 1956.

Handlin, Oscar. John Dewey's Challenge to Education: Historical Perspectives on the Cultural Context. New York: Harper and Brothers, 1959.

Higham, John. Strangers in the Land: Patterns of American Nativism, 1860-1925. New York: Antheneum, 1970.

Jackson, Kenneth T. The Ku Klux Klan in the City, 1915-1930. New York: Oxford University Press, 1967.

Jorgenson, Lloyd P. "The Oregon School Law of 1922: Passage and Sequel." The Catholic Historical Review. IIV (October, 1968), p. 458 .

Knuth, Priscilla F. "Nativism in Oregon." Unpublished senior thesis, Reed College, 1947.

Margulis, Herbert F. "The Rise and Fall of the Ku Klux Klan in the 1920's." Unpublished senior thesis, Reed College, 1950.

Mowry, George E., editor. The Twenties: Fords, Flappers \& Fanatics. Englewood Cliffs: Prentice Hall, 1963.

Noble, David W. The Paradox of Progressive Thought. Minneapolis: University of Minnesota Press, 1958.

Passi, Michael. "Albert Jencks and the Minnesota Movement to Professionalize Americanization Work, 1918-1925." Unpublished paper, Portland State University, 1971.

Peil, A.A. "Old Oregon School Days." Oregon Historical Quarterly, Vol. 59 (September, 1958).

Resek, Carl, editor. The Progressives. The American Heritage Series. New York: Bobbs-Merrill Company, 1967.

Schlesinger, Arthur M., Jr. and White, Morton G. Paths of American Thought. Boston: Houghton Mifflin Company, 1963.

Schreibies, Charles D. Pioneer Education in the Pacific Northwest, 1787-1847. Portland: Metropolitan Press, 1936. 
Toy, Eckard V., Jr. "The Ku Klux Klan in Tillamook, Oregon." Pacific Northwest Quarterly, Vol. 53 (April, 1962), p. 60.

Tyack, David. "Community Control in Rural Education: The Tribe and the Common School." American Quarterly, XXIV (March, 1972), p. 4 .

Tyack, David. "The Kingdom of God and the Common School: Protestant Ministers and the Educational Awakening in the West." Harvard Educational Review. Vol. 36 (Fall, 1966), p. 448.

Tyack, David. "The Perils of Pluralism: The Background of the Pierce Case." American Historical Revicw, IXX (October, 1968), p. 74.

Welter, Rush. Popular Education and Democratic Thought in America. New York: Columbia University Press, 1962.

White, Morton G. Social Thought in America: the Revolt Against Formalism. New York: The Viking Press, 1949. 